\title{
Perilaku Seksual Remaja di Lingkungan Lokalisasi Kabupaten Sidoarjo
}

\author{
Mustalia "), Antono Suryoputro**), Bagoes Widjanarko**) \\ * Jurusan Kebidanan STIKES Artha Bodhi Iswara Surabaya \\ Email: mustalia25@yahoo.co.id \\ * Magister Promosi Kesehatan Universitas Diponegoro Semarang
}

\begin{abstract}
ABSTRAK
Perilaku seksual merupakan segala tingkah laku yang didorong oleh hasrat seksual, baik bagi lawan jenis maupun sesame jenis. Tujuan penelitian untuk mengetahui perilaku seksual remaja dilingkungan Lokalisasi Kabupaten Sidoarjo. Hal ini dilakukan penelitian karena masih tingginya perilaku seksual remaja yang terjadi dilingkungan Lokalisasi. Penelitian ini merupakan penelitian kuantitatif secara cross sectional, pengambilan sampel secara minmal sample size. Penelitian ini dilaksanakan dilingkungan Lokalisasi Kabupaten Sidoarjo dilakukan dengan menilai perilaku remaja pada lembar kuesioner. Populasi penelitian disini adalah remaja yang tinggal dilingkungan Lokalisasi Kabupaten Sidoarjo sebanyak 221 responden dengan sampel 140 responden. Yang menjadi criteria inklusi yaitu remaja yang tinggal dililngkungan Lokalisasi, berusia 12-18 tahun, belum menikah, bukan pekerja seks dan bersedia menjadi responden. Yang menjadi variabel terikat dan variabel bebas adalah perilaku seksual. Data yang terkumpul diolah dengan menggunakan uji chi square menunjukkan bahwa nilai $\mathrm{p}$ value $>0,05$. Kesimpulan dari penelitian menunjukkan adanya perilaku seksual remaja dilingkungan Lokalisasi Kabupaten Sidoarjo.
\end{abstract}

Kata kunci : Perilaku seksual, Remaja

\section{ABSTRACT}

Sexual behavior as every conducts driven by sexual desire, either for other sex or even same sex. The purpose of this research to recognize Adolescent Sexual behavior in localization area of Sidoarjo regency. It is done a research due to still high adolescent sexual behavior happened in localization. This research as quantitave research with cross-sectional sampling with minimally sample size. This research performed in localization of Sidoarjo regency done by assessing adolescent in questionnaire sheet. Population of the research is teenager who lived at localization area of Sidoarjo regency as 221 respondents with sample of 140 respondets. Become inclusive criteria that is teenage who lived around localization area, age 12-18 years old, unmarried, not prostitute and ready to be respondent. Which become dependent variable and independent variable are sexual behavior. Data collected then processed by using chi square test indicating that $p$ value $>0,05$. Conclusion of this research show there is adolescent sexual behavior in localization area of Sidoarjo regency.

Keywords: sexual behavior

\section{PENDAHULUAN}

Seks pranikah bagi masyarakat Indonesia masih dipandang sebagai perbuatan yang tidak bisa diterima baik secara sosial maupun budaya. Meskipun saat ini kaum muda cenderung lebih toleran terhadap hal ini. Beberapa penelitian menunjukkan bahwa banyak kaum muda yang melakukan hubungan seks pranikah. Tinjauan terhadap beberapa penelitian seksual remaja di Indonesia tahun 19982002 yaang dilakukan Shaluhiyah menunjukkan bahwa remaja yang 
melakukan premarital seks berkisar antara 2 sampai 27 persen.

Penelitian lain tentang perilaku seks remaja (12-24 tahun) belum menikah yang dilakukan di empat kota besar di Indonesia yaitu Jakarta, Surabaya, Medan dan Bandung pada tahun 2004 melaporkan bahwa rata-rata remaja melakukan hubungan seks pertama kali pada umur 18 tahun, 26 persen diantaranya mengaku pertama kali melakukan hubungan seks pada usia 13-15 tahun.

Meskipun banyak penelitian seksualitas remaja telah dilakukan di Indonesia namun masih sedikit penelitian yang dilakukan pada remaja yang tinggal dilingkungan Lokalisasi pada umumnya mengenai pencegahan infeksi menular seksual (IMS), HIV/AIDS, akses pelayanan kesehatan serta penggunaan kondom pada pekerja seks dan pelanggannya. Padahal di Lokalisasi terdapat banyak keluarga yang tinggal disana bersama anak-anak remaja.

Data di Departemen Kesehatan RI tahun 2006 menunjukkan dari jumlah kasus HIV dan AIDS yang ditemukan, pekerja seks komersial (PSK) dengan jumlah sebanyak 129.000 mempunyai kontribusi dan menyumbang penderita HIV adalah 3.795 orang atau $2,9 \%$.

Pada tahun 2006 tercatat 1.184 kasus dengan rincian 830 penderita HIV dan 240 penderita AIDS di Jawa Tengah. Sedangkan dari total penderita AIDS, 137 diantaranya meninggal. Pada Desember 2008 secara kumulatif kasus HIV/AIDS menjadi 1.915 orang yang terdiri dari penderita HIV positif sebanyak 1.375 orang dan AIDS sebanyak 540 orang, sebanyak 215 orang telah meninggal dunia.

Di Kabupaten Sidoarjo dari data yang dilaporkan pada Dinas Kesehatan menunjukkan bahwa ada peningkatan penderita HIV yang sangat signifikan yaitu sampai pada tahun 2011 jumlah penderita kasus HIV sebanyak 296 penderita, kasus AIDS sebanyak 439 penderita, kasus IMS sebanyak 93 penderita, dan jumlah kasus kematian akibat AIDS sebanyak 214 penderita. Sedangkan hasil Serro Survey yang dilakukan oleh Dinas Kesehatan Kabupaten Sidoarjo menunjukkan dari tahun ke tahun terus mengalami kenaikan sampai tahun 2011.

$$
\text { Data hasil Liponsos Dinas }
$$

Kesehatan Kabupaten Sidoarjo di tiga Lokalisasi yaitu Randu Pitu (candi), pasar sapi (Krian) dan tangkis pondok indah (Porong) menunjukkan tahun 2011 penyakit HIV/AIDS semakin meningkat, selain itu letak Lokalisasi sangat strategis berada ditegah kota dengan harga relative terjangkau sehingga Lokalisasi besar kemungkinan mempunyai kontribusi terhadap penularan IMS dan HIV/AIDS.

Remaja yang tinggal dilingkungan Lokalisasi pada umumnya adalah anak para mucikari atau orang-orang yang 
mempunyai usaha dikomplek tersebut. Mereka tinggal di lingkungan yang permisif terhadap hubungan seks diluar nikah. Rumah yang mereka tinggali digunakan juga sebagai tempat transaksi seks dan karaoke. Setiap hari mereka terpapar oleh berbagai kegiatan prostitusi seperti melihat perempuan berpakaian seksi dengan gaya duduk, berjalan, memandang dan bicara yang menantang. Orang secara terbuka berpelukan, berciuman dan saling merayu. Disis lain, prostitusi oleh masyarakat umum dipandang rendah dan tidak bermoral sehingga orang-orang yang tinggal dikomplek Lokalisasi juga sering mendapat stigma dari masyarakat. Hal ini menjadikan remaja yang tinggal dilingkungan Lokalisasi kadang merasa minder dan mempunyai self-esteem yang rendah. (Widyastuti, 2009)

Pernyataan tersebut diperkuat oleh Bandura dalam konsepnya reciprocal determinism, yaitu seseorang akan bertingkah laku dalam situasi yang ia pilih secara aktif. Dalam menganalisis perilaku seseorang, ada tiga komponen yang harus ditelaah yaitu individu itu sendiri $(\mathrm{P}$ : Person), lingkungan (E : Environment), serta perilaku individu tersebut (B : Behavior). Individu akan memunculkan satu bentuk perilaku yang berbeda meskipun lingkungan serupa, namun individu akan bertingkah laku setelah ada proses kognisi atau penilaian terhadap lingkungan sebagai stimulus yang akan ditindaklanjuti. Bandura menyatakan bahwa kognisi adalah sebagai tingkah laku perantara dimana persepsi diri kita mempengaruhi tingkah laku. (Sarwono, 2003)

\section{METODE}

Metode penelitian yang digunakan dalam penelitian ini adalah Explanatory Research dengan menggunakan rancangan penelitian cross sectional. Penelitian ini dilakukan dengan metode kuantitatif dimana akan diukur perilaku seksual remaja di lingkungan Lokalisasi Kabupaten Sidoarjo. Populasi dalam penelitian ini adalah remaja yang tinggal di lingkungan Lokalisasi Kabupaten Sidoarjo, dimana remaja yang berusia 12-18 tahun. Jumlah remaja di Kecamatan Porong ada 131 remaja, Kecamatan Krian ada 145 remaja, Kecamatan Candi ada 45 remaja. Jadi jumalah remaja di lingkungan Lokalisasi dalam tiga Kecamatan berjumlah 221 remaja.

Teknik pengambilan sampel ditentukan jumlah sampelnya dengan table Kretjie ukuran kesalah 5\% atau tingkat kepercayaan 95\%, didapatkan sebanyak 140 remaja. Sampel dalam penelitian ini merupakan total sampel dengan menggunakan minmal sample size menurut Lemeshow. Alat yang digunakan dalam penelitian ini adalah kuesioner yang 
berisikan pernyataan dan pertanyaan yang berhubungan dengan variabel peneltian. Teknis analisis data meliputi analisis univariat, analisis bivariat menggunakan uji chi square dan analisis multivariate menggunakan regresi logistic.

\section{HASIL DAN PEMBAHASAN}

\section{Karakteristik}

\section{Perilaku seksual remaja}

Hubungan perilaku seksual remaja dalam penelitian ini dibagi dua kategori yaitu berisiko perilaku seksual dan tidak berisiko perilaku seksual dengan jumlah responden yaitu 140 remaja yang tinggal dlingkungan Lokalisasi Kabupaten Sidoarjo. Hasil penelitian berdasarkan hasil analisis univariat responden yang berada tinggal dilingkungan Lokalisasi Kabupaten Sidoarjo lebih sedikit yang mengalami perilaku seksual berisiko 16 $(11,4 \%)$ dibandingkan dengan remaja yang mengalami perilaku seksual tidak berisiko $124(88,6 \%)$. Dapat disimpulkan bahwa remaja yang tinggal dilingkungan Lokalisasi Kabupaten SIdoarjo tidak selalu memiliki perilaku yang buruk terutama tentang hubungan seksual berisiko IMS, hal ini dikarenakan remaja paham akan tentang pengetahuan kesehatan reproduksi. Dengan adanya hubungan seksual berisiko pada remaja yang tinggal dilingkungan Lokalisasi, dikarenakan sebagian kecil remaja tidak tinggal dengan orang tuanya
$(27,9 \%)$, harga diri rendah $(31,4 \%)$, efikasi diri rendah $(30,7 \%)$, pengaruh orang tua dengan control kurang $(22,9 \%)$ dan pengaruh teman sebaya dengan pengaruh jelek $(29,3 \%)$.

Dari hasil penelitian ini variabel independen yang mempunyai pengaruh paling besar pada perilaku seksual remaja yang tinggal dilingkungan Lokalisasi Kabupaten Sidoarjo adalah pengaruh orang tua dan harga diri. Pada responden yang tinggal dilingkungan Lokalisasi Kabupaten Sidoarjo variabel pengaruh orang tua dengan odds ratio (OR) sebesar 21,191 yang artinya responden yang memiliki pengaruh orang tua dengan control baik mempunyai peluang tidak terjadinya memiliki perilaku seksual berisiko dibandingkan responden yang memiliki pengaruh orang tua dengan control kurang. Dan harga diri dengan odds ratio (OR) sebesar 17,480 yang artinya responden yang memiliki harga diri yang baik mempunyai peluang tidak terjadi perilaku seksual berisiko dibandingkan dengan responden yang memiliki harga diri jelek.

\section{Umur responden}

Hasil analisis univariat menunjukkan bahwa remaja yang berada pada rentang usia 15-18 tahun. Jumlah responden remaja awal (berusia <17 tahun) sebanyak 52,9\% dan jumlah responden remaja akhir (berusia $\geq 17$ tahun) sebanyak $47,1 \%$. 


\section{Jenis kelamin}

Pada penelitian ini melibatkan responden laki-laki maupun perempuan. Dari hasil penelitian diperoleh bahwa jenis kelamin laki-laki terhadap perilaku seksual berisiko sebanyak $(7,9 \%)$ responden dan jenis kelamin perempuan dengan perilaku seksual berisiko sebanyak (14,3\%), sehingga ada kecenderungan responden perempuan cenderung melakukan perilaku seksual berisiko terhadap IMS.

\section{Tingkat pendidikan ibu}

Menunjukkan distribusi persentase responden berdasarkan tingkat pendidikan ibu, sebagian besar ibu responden tingkat pendidikan menengah sebanyak $65,0 \%$, tingkat pendidikan dasar ibu responden sebanyak $35,0 \%$.

\section{Tingkat pendidikan ayah}

Menunjukkan distribusi persentase responden berdasarkan tingkat pendidikan ayah, sebagian besar ayah responden tingkat pendidikan menengah sebanyak $71,4 \%$, tingkat pendidikan dasar ibu responden sebanyak $28,6 \%$.

\section{Tempat tinggal}

Tempat tinggal adalah Lokasi tempat tinggal responden selama bersekolah. Dalam penelitian menemukan bahwa remaja yang tempat tinggalnya juga bisa dipengaruhi dari faktor internal dan eksternal. Hasil analisis univariat menunjukkan bahwa responden yang tinggal dilingkungan Lokalisasi Kabupaten Sidoarjo lebih banyak yang tempat tinggalnya dengan orang tua sendiri $(72,15 \%)$ daripada remaja yang tidak tinggal dengan orang tuanya sebanyak $(27,9 \%)$.

\section{Pekerjaan orang tua}

Menunjukkan distribusi bahwa sebagian besar persentase responden berdasarkan pekerjaan orang tua yang bekerja sebanyak 52,9\% dan pekerjaan orang tua yang tidak bekerja sebanyak sebanyak 47,1\%. Jawaban distribusi menunjukkan distribusi responden menurut pekerjaan orang tua responden dengan perilaku seksual.

\section{Harga diri}

Hasil analisis univariat menunjukkan lebih dari $(25,0 \%)$ responden remaja yang tinggal dilingkungan Lokalisasi Kabupaten Sidoarjo mempunyai harga diri yang tinggi terhadap perilaku seksual berisiko, dan $(5,2 \%)$ mempunyai harga diri yang rendah terhadap perilaku seksual berisiko. Harga diri yang paling banyak mempunyai jawaban sangat setuju adalah responden merasa kegagalan tidak akan membuat jadi kecewa atau merasa 
kurang bila dibandingkan dengan orang lain $(70,9 \%)$ dan responden merasa tidak suka mencari kesalahan yang ada pada keluarga dan orang lain $(65,0 \%)$. Perubahan yang cepat secara fisik yang juga disertai kematangan seksual terkadang membuat remaja merasa tidak yakin akan diri sendiri dan kemampuan mereka sendiri. Perubahan fisik yang terjadi secara cepat, baik perubahan internal maupun eksternal sangat berpengaruh terhadap konsep diri remaja.

Hasil penelitian menunjukkan distribusi presentase responden berdasarkan harga diri, sebagian besar responden yang harga dirinya tinggi sebanyak $68,6 \%$ dan harga dirinya rendah sebanyak $31,4 \%$. Hasil responden per item diketahui sebanyak $53,6 \%$ responden tidak pernah merasa malu atau menyalahkan diri sendiri atau mearasa bersalah selama ini, sebanyak 70,9\% responden merasa kegagalan tidak akan membuat jadi kecewa atau merasa kurang bila dibandingkan dengan orang lain, sebanyak 59,3\% responden ikut berbahagia dan senang bila ada teman yang mendapat keberuntungan dan kemenangan, sebanyak $65,0 \%$ responden merasa tidak suka mencari kesalahan yang ada pada keluarga dan orang lain, dan 50,7\% responden tidak akan menyalahkan orang lain karena kesalahan masalah yang dihadapi.

Dapat diketahui bahwa persentase remaja yang berisiko perilaku seksual lebih banyak pada remaja yang mempunyai harga diri rendah sekitar $25,0 \%$ dibandingkan pada kelompok remaja yang mempunyai harga diri tinggi sekitar 5,2\%. Sedangkan persentase remaja yang tidak berisiko perilaku seksual lebih banyak pada remaja yang mempunyai harga diri tinggi sekitar 94,8\% dibandingkan pada remaja yang mempunyai rendah sekitar 75,0\%. Hasil uji chi square menunjukkan bahwa nilai $\mathrm{p}$ value > 0,05 jadi Ho di tolak, sehingga dapat disimpulkan bahwa ada hubungan antara harga diri dengan perilaku seksual remaja dilingkungan Lokalilsasi Kabupaten Sidoarjo.

Hasil uji bivariat antara self esteem (harga diri) dengan perilaku seksual pranikah di dapatkan Nilai statistik yang diperoleh yaitu nilai $p$ value $=0,002$ pada responden juga menunjukkan adanya hubungan antara kedua variabel tersebut. Menurut Baumster (2001) yang dikutip oleh Longmore menyampaikan bahwa beberapa ahli berusaha meyakinkan bahwa harga diri yang tinggi tidak selalu mencegah semua jenis resiko karena harga diri cenderung merupakan hasil, bukan penyebab perilaku yang berhasil ${ }^{55)}$.

Hasil penelitian didapatkan angka p. value $=0,002$ dan OR $(\operatorname{Exp} B)=17.480$ berarti responden dengan harga diri rendah kemungkinan untuk melakukan perilaku seksual berisiko 17 kali lebih besar dari pada remaja yang mempunyai harga diri tinggi. Harga diri merupakan turunan dari 
konsep diri, yang merupakan salah satu aspek kepribadian. Dalam beberapa penelitian menemukan bahwa harga diri mempengaruhi konformitas, ketertarikan antar individu, perilaku yang bermoral, orientasi pendidikan dan berbagai aspek kepribadian serta kesehatan jiwa.

\section{Pusat pengendalian diri}

Hasil analisis univariat menunjukkan bahwa pusat pengendalian diri dari dalam terhadap perilaku seksual berisiko sebanyak $(5,1 \%)$, sedangkan pusat pengendalian diri dari luar terhadap perilaku seksual berisiko sebanyak $(26,2 \%)$, sehingga pusat pengendalian diri dari luar bias mempengaruhi responden berperilaku seksual IMS.

Hasil distribusi mayoritas responden memiliki pusat pengendalian diri dari dalam sebanyak 70,0\%, dan responden yang memiliki pusat pengendalian diri dari luar sebanyak $30,0 \%$. Hasil responden per item diketahui sebanyak 70,0\% responden tidak pernah tahu dimana posisi/status saya sebenarnya bila dibandingkan orang lain (teman), 85,5\% responden tidak berhasil dalam mengerjakan tugas, saya cenderung menyerah, 62,9\% responden mengatakan pernikahan merupakan peristiwa "gambling” (untung-untungan) bagi sebagian besar orang, dan $86,4 \%$ responden mengatakan orang lain atau teman terdekat saya biasa mengontrol hidup saya.
Distribusi responden menurut pusat pengendalian diri dengan perilaku seksual. Dapat di ketahui bahwa persentase remaja yang berisiko perilaku seksual lebih banyak pada remaja yang mempunyai pusat pengendalian dari luar 26,2\% dibandingkan pada remaja yang mempuyai pusat pengendalian diri dari dalam $5,1 \%$. Sedangkan persentase remaja yang tidak berisiko perilaku seksual lebih banyak pada remaja yang mempunyai pusat pengenalian diri dari dalam 94,9\% dibandingkan pada remaja yang mempunyai pusat pengendalian diri dari luar 73,8\%.Berdasarkan hasil uji chi square menunjukkan bahwa nilai $\mathrm{p}$ value > 0,05 jadi Ho di tolak, sehingga dapat disimpulkan bahwa ada hubungan antara pusat pengendalian diri dengan perilaku seksual remaja dilingkungan Lokalilsasi Kabupaten Sidoarjo.

Berdasarkan analisa bivariat diperoleh hasil bahwa ada hubungan secara signifikan antara variabel pusat pengendalian diri dengan perilaku seksual berisiko ( $p$ value $=0,001)$, artinya bahwa ada hubungan antara pusat pengendalian diri dengan perilaku seksual remaja yang tinggal dilingkungan Lokalisasi Kabupaten Sidoarjo.

\section{Pengetahuan tentang kesehatan reproduksi IMS dan HIV/AIDS}


Hasil penelitian menunjukkan bahwa mayoritas responden memiliki pengetahuan tentang kesehatan reproduksi IMS dan HIV/AIDS yang kurang sebanyak $32,1 \%$, dan responden yang memiliki pengetahuan baik sebanyak 67,9\%. Hasil jawaban responden tentang definisi reproduksi diketahui sebanyak 37,9\% responden menjawab sperma diproduksi oleh testis hingga matang selama 72 jam sebanyak $35,7 \%$ responden, muncul keinginan hasrat seksual, 100,0\% wanita menjadi hamil saat melakukan hubungan seksual pertama kali, 100,0\% wanita menjadi hamil apabila melakukan hubngan seksual hanya satu kali, $82,1 \%$ aborsi dapat dilakukan dengan cara makan nanas, $100,0 \%$ tingkat resiko seseorang terkena IMS bila melakukan hubungan seksual dengan orang yang terinfeksi tanpa memakai kondom, 100,0\% pergi ke dukun, $79,3 \%$ diare yang tidak sembuh-sembuh, 100,0\% HIV/AIDS dapat disembuhkan dan $100,0 \%$ mengetahui tentang kontrasepsi.

Hasil penelitian dapat diketahui bahwa persentase remaja yang berisiko perilaku seksual lebih banyak pada remaja yang mempunyai pengetahuan yang kurang 22,2\% dibandingkan pada remaja yang mempunyai pengetahuan baik $6,3 \%$. Sedangkan persentase remaja yang tidak berisiko perilaku seksual lebih banyak pada remaja yang mempunyai pengetahuan baik 93,7\% dibandingkan pada remaja yang mempunyai pengetahuan kurang $77,8 \%$. Berdasarkan hasil uji chi square menunjukkan bahwa nilai $\mathrm{p}$ value > 0,05 jadi Ho di terima, sehingga dapat disimpulkan bahwa tidak ada hubungan antara pengetahuan kesehatan reproduksi IMS dan HIV/AIDS dengan perilaku seksual remaja di lingkungan Lokalilsasi Kabupaten Sidoarjo.

Analisis univariat pada penelitian menunjukkan bahwa terdapat sebagian besar remaja awal $(52,9)$ yang tinggal dilingkungan Lokalisasi Kabupaten Sidoarjo. Analisis bivariat dan multivariate pada responden remaja yang tinggal dilingkungan Lokalisasi mendapatkan hasil bahwa responden yang berpengetahuan kurang terhadap perilaku seksual berisiko sebanyak (22,2\%) dan yang berpengetahuan baik terhadap perilaku seksual berisiko sebanyak (6,3\%). Hasil uji statistic multivariate didapatkan nilai p.value $=0,013$ dan nilai OR $(\operatorname{Exp} B)=$ 2,638 - 170,235. Berarti responden dengan pengetahuan kurang, mempunyai kemungkinan untuk melakukan perilaku seksual berisiko dibandingkan dengan responden yang mempunyai pengetahuan baik.

\section{Sikap terhadap seksual}

Menunjukkan bahwa mayoritas responden memiliki sikap tidak permisif terhadap seksual berisiko sebanyak $60,7 \%$, 
dan responden yang memiliki sikap permisif terhadap seksual berisiko sebanyak 39,3\%. jawaban responden remaja dilingkungan Lokalisasi Kabupaten Sidoarjo mayoritas responden menyatakan bahwa sebaiknya hubungan seksual dilakukan setelah menikah $75,5 \%$ dan 79,3\% responden menyatakan menggunakan kontrasepsi merupakan suatu tindakan yang bertanggung jawab, 80,0\% responden menyatakan kontrasepsi bertujuan untuk mencegah penyakit menular seksual (PMA dan HIV/AIDS), $81,4 \%$ responden menjawab kumpul kebo atau tinggal serumah dengan pasangan tanpa nikah adalah perbuatan yang tidak bermoral dan tidak bias diterima oleh masyarakat, 100,0\% responden menyatakan pekerja seks komersial (PSK) merupakan pekerjaan tidak bermoral karena menurunkan martabat seseorang serta tidak biasa diterima oleh masyarakat dan $80,0 \%$ responden menyatakan pornografi adalah hal yang harus dihindari oleh remaja.

Menunjukkan penelitian dapat di ketahui persentase remaja yang berisiko perilaku seksual lebih banyak pada remaja yang bersikap permisif terhadap perilaku seksual 20,0\% dibandingkan pada remaja yang bersikap tidak permisif terhadap perilaku seksual 5,9\%. Sedangkan persentase remaja yang tidak berisiko perilaku seksual lebih banyak pada remaja yang bersikap tidak permisif terhadap perilaku seksual 94,1\% dibandingkan pada remaja yang bersikap permisif terhadap perilaku sekasual $80,0 \%$. Berdasarkan hasil uji chi square menunjukkan bahwa nilai $\mathrm{p}$ value > 0,05 jadi Ho di terima, sehingga dapat disimpulkan bahwa tidak ada hubungan antara sikap terhadap seksual dengan perilaku seksual remaja dilingkungan lokalilsasi Kabupaten Sidoarjo.

Sikap terhadap seksualitas adalah keyakinan, evaluasi dan kecenderungan untuk bertindak responden terhadap berbagai hal yang terkait dengan seksualitas. Hasil penelitan ini menunjukkan bahwa sebagian besar responden bersikap tidak permisif $(60,7 \%)$ lebih besar daripada responden yang bersikap permisif $(39,3 \%)$. Sehingga ada kecenderungan melakukan perilaku seksual berisiko IMS dan HIV/AIDS. Sedangkan berdasarkan analisa bivariat diperoleh hasil bahwa tidak ada hubungan antara sikap terhadap perilaku seksual.

Hasil analisa bivariat menunjukkan bahwa variabel efikasi diri dengan perilaku seksual yang berisiko terhadap IMS secaraa statistic menunjukkan adanya hubungan signifikan $(\mathrm{p}$ value $=0,022)$, artinya bahwa responden yang mempunyai sikap terhadap perilaku seksual. Beberapa hal yang dapat memberikan gambaran tingkat tidak permisif responden dapat dilihat dari jawaban responden pada pertanyaan- 
pertanyaan mengenai hubungan seksual, dimana jawaban (75,5\%) mengenai hubungan seksual dilakukan setelah menikah, $(79,3 \%)$ reponden menyatakan menggunakan kontrasepsi, (80,0\%) responden menyatakan kontrasepsi bertujuan untuk mencegah penyakit menular seksual, $(81,4 \%)$ responden menjawab kumpul kebo atau tinggal serumah dan $(80,0 \%)$ responden menyatakan pornografi harus dihindari oleh remaja.

\section{Efikasi diri}

Menunjukkan tentang efikasi diri terhadap perilaku seksual responden yang tinggi sebanyak 69,3\% dan efikasi diri terhadap perilaku seksual responden yang rendah sebanyak $30,7 \%$. Persentase remaja yang berisiko perilaku seksual lebih banyak pada remaja yang mempunyai kemampuan efikasi diri tinggi yaitu 4,1\% dibandingkan pada remaja yang mempunyai kemampuan efikasi diri tinggi yaitu 4,1\%. Sedangkan persentase remaja yang tidak berisiko perilaku seksual lebih banyak pada remaja yang mempunyai kemampuan efikasi diri tinggi 95,9\% dibandingkan pada remaja yang mempunyai kemampuan efikasi diri rendah yaitu $72,1 \%$. Berdasarkan hasil uji chi square menunjukkan bahwa nilai $\mathrm{p}$ value > 0,05 jadi Ho di tolak, sehingga dapat disimpulkan bahwa ada hubungan antara efikasi diri dengan perilaku seksual remaja dilingkungan Lokalilsasi Kabupaten Sidoarjo.

Hasil penelitian menunjukkan bahwa $(69,3 \%)$ efikasi diri yang tinggi dan $(30,7 \%)$ efikasi rendah. Hal ini dapat dilihat pada pertanyaan dalam kuesioner diantaranya adalah $(90,7 \%)$ responden keputusan untuk tidak melakukan hubungan seksual, (89,3\%) responden dapat untuk tidak melakukan seks sebelum menikah, $(85,7 \%)$ responden tidak melakukan hubungan seks dengan pacar walaupun harus memutuskan hubungan, $(90,0 \%)$ responden tidak melakukan hubungan seks dengan pacar walaupun teman berpendapat hal tersebut tidak masalah, $(88,6 \%)$ responden berhenti untuk menemui pacarnya jika memaksa untuk melakukan hubungan seks dan (79,3\%) responden melarang pacarnya untuk masuk ke kamar.

Hasil penelitian menunjukkan bahwa responden yang memiliki perilaku seksual, persentase responden yang mempunyai efikasi diri yang rendah $(27,9 \%)$ lebih besar dari pada responden yang mempunyai efikasi diri yang tinggi (4,2\%), sehingga ada ada kecenderungan melakukan perilaku seksual.

Hasil analisa bivariat menunjukkan bahwa variabel efikasi diri dengan perilaku seksual yang berisiko terhadap IMS secara statistic menunjukkan adanya hubungan signifikan $(\mathrm{p}$ value $=0,000)$. Temuan dalam 
penelitian ini artinya bahwa remaja dengan efikasi diri yang rendah mempunyai kecenderungan untuk berperilaku seksual berisiko IMS remaja yang memiliki efikasi diri yang tinggi mempunyai kemampuan dalam mencegah bagaimana tidak melakukan perillaku seksual berisiko IMS. Variabel efikasi diri berhubungan signifikan terhadap perilaku seksual pranikah dengan OR (Exp b) 8,897 (95\% CI : 1,423-55,640 ). Hal ini berarti bahwa responden dengan efikasi diri yang rendah memiliki kecenderungan lebih besar untuk melakukan perilaku seksual berisiko IMS dibandingkan dengan responden yang memiliki efikasi diri yang tinggi.

\section{Pengaruh teman sebaya}

Dapat di ketahui bahwa persentase remaja yang berisiko perilaku seksual lebih banyak pada kelompok remaja dengan pengaruh teman sebaya yang jelek yaitu 29,3\% dibandingkan pada remaja dengan pengaruh teman sebaya yang baik yaitu $4,0 \%$. Sedangkan persentase remaja yang tidak berisikolebih banyak pada remaja dengan pengaruh teman sebaya yang baik 96,0\% dibandingkan pada remaja dengan pengaruh teman sebaya yang jelek $70,7 \%$. Berdasarkan hasil uji chi square menunjukkan bahwa nilai $\mathrm{p}$ value $>0,05$ jadi Ho di tolak, sehingga dapat disimpulkan bahwa ada hubungan antara teman sebaya dengan perilaku seksual remaja di lingkungan Lokalisasi Kabupaten Sidoarjo.

Pengaruh dari teman sebaya dapat menjadi positif maupun negatif, dan sikap yang negatif cenderung akan merusak dan mengabaikan nilai-nilai dan kontrol orang tua, seperti pernyataan mereka bahwa dari $(63,6 \%)$ responden menyatakan bahwa teman-teman ada yang berciuman bibir dengan pacarnya, $(19,3 \%)$ responden tidak peduli melakukan hubungan seksual dengan pacar dan $(85,0 \%)$ responden malu untuk berdiskusi tentang perilaku seksual dengan teman.

Hasil penelitian ini menunjukkan bahwa responden yang terpengaruh baik oleh teman sebaya sebanyak $(70,7 \%)$ dari pada pengaruh buruk oleh teman sebaya (29,3\%), sehingga ada kecenderungan responden yang memiliki teman sebaya dengan pengaruh buruk cenderung melakukan perilaku seksual. Berdasarkan analisa bivariat diperoleh hasil bahwa variabel pengaruh teman sebaya secara statistik dengan perilaku seksual menunjukkan ada hubungan yang signifikan ( $p$ value $=0,000)$, artinya bahwa responden yang mempunyai pengaruh teman sebaya yang buruk kecenderungan untuk berperilaku seksual.

\section{Pengaruh orang tua}

Hasil penelitian faktor orang tua dengan perilaku seksual diketahui 
persentase remaja yang berisiko perilaku seksual lebih banyak pada remaja yang dapat pengaruh dari faktor orang tua yang control kurang yaitu $34,4 \%$ dibandingkan pada remaja yang dapat pengaruh dari faktor orang tua yang control baik yaitu $4,6 \%$. Sedangkan persentase remaja yang tidak berisiko perilaku seksual lebih banyak pada remaja yang dapat pengaruh dari faktor orang tua yang control baik $95,4 \%$ dibandingkan pada remaja yang dapat pengaruh dari faktor orang tua yang control kurang 65,6\%. Berdasarkan hasil uji chi square menunjukkan bahwa nilai $\mathrm{p}$ value > 0,05 jadi Ho di tolak, sehingga dapat disimpulkan bahwa ada hubungan antara pengaruh orang tua dengan perilaku seksual remaja dilingkungan Lokalilsasi Kabupaten Sidoarjo.

Pengaruh orang tua yaitu upaya orang tua dalam memonitor dan mengamati aktivitas responden sehari-hari. Hasil penelitian menunjukkan hampir sebagian orang tua tidak segan untuk memberikan informasi tentang kehamilan $(89,0 \%)$ dan orang tua marah jika saya bertanya tentang hubungan seksual $(92,1 \%)$.

Hasil penelitian menunjukkan bahwa responden yang pengaruh orang tua dengan control kurang $(34,4 \%)$ memiliki perilaku seksual berisiko lebih besar daripada responden yang memiliki pengaruh orang tua dengan control baik (4,6\%). sehingga ada kecenderungan remaja yang memiliki pengaruh orang tua dengan control kurang untuk melakukan perilaku seksual berisiko. Hasil analisis bivariat menunjukkan bahwa variabel sikap orang tua secara statistik menunjukkan hubungan yang signifikan dengan perilaku seksual pranikah berisiko IMS ( $p$ value $=0,000$ ), artinya bahwa responden yang pengaruh orang tua dengan control kurang terhadap perilaku seksual berisiko dan remaja tidak mau mengikuti atau tidak sejalan dengan pengaruh orang tuanya maka kemungkinan dia tidak akan dapat menghindari perilaku seksual berisiko.

Setelah dilakukan analisis multivariat dengan regresi logistik menggunakan metode enter diperoleh bahwa variabel pengaruh orang tua berhubungan signifikan terhadap perilaku seksual berisiko dengan OR 21,191 (95\% CI: 2,638 - 170,235). Hal ini berarti bahwa responden yang memiliki pengaruh orang tua dengan control kurang memiliki kecenderungan 21 kali lebih besar untuk melakukan perilaku seksual berisiko IMS dibandingkan dengan responden yang pengaruh orang tua dengan control lebih. Hal ini tidak sesuai dengan penelitian PKBI, yang menyatakan bahwa keluarga yang mampu berfungsi secara optimal, akan membatu remaja untuk dapat menyalurkan dorongan seksualnya dengan cara yang selaras dengan norma dan nilai yang 
berlaku serta menyalurkan energi psikis secara produktif.

\section{Hasil Pengolahan Data dengan Regresi Logistic}

Berdasarkan hasil penelitian dapat diketahui bahwa terdapat 9 step analisa regresi logistic ganda, dimana terbukti berpengaruh perilaku seksual berisiko IMS pada step 9 yaitu tempat tinggal, harga diri, efikasi diri, pengaruh orang tua dan pengaruh teman sebaya. Dimana semuanya mempunyai nilai $\mathrm{p}$ value $<0,05$. Dari ke kelima variabel tersebut yang berpengaruh paling dominan adalah pengaruh orang tua dengan nilai odds ratio (OR) sebesar 21,191 dengan OR sebesar 21,191 dapat diartikan bahwa remaja dengan pengaruh orang tua yang dengan kontrol kurang mempunyai kemungkinan untuk melakukan perilaku seksual berisiko 21 kali lebih besar dari pada remaja yang mempunyai pengaruh orang tua dengan control kurang yang pengaruh orang tua dengan control lebih. Harga diri dengan nilai odds ratio (OR) 17,480 dapat diartikan bahwa remaja dengan harga diri rendah mempunyai kemungkinan untuk melakukan perilaku seksual berisiko 17 kali lebih besar dari pada remaja yang mempunyai harga diri tinggi.

\section{SIMPULAN}

Variabel yang berhubungan dengan perilaku seksual remaja yang tinggal dilingkungan Lokalisasi Kabupaten Sidoarjo adalah tempat tinggal remaja yang tidak tinggal dengan orang tuanya terhadap perilaku seksual berisiko sebanyak $28,2 \%$, harga diri yang rendah terhadap perilau seksual berisiko sebanyak $25,0 \%$, pusat pengendalian diri dari luar terhadap perilaku seksual berisiko sebanyak $26,2 \%$, efikasi diri yang rendah terhadap perilaku seksual berisiko sebanyak $27,9 \%$, pengaruh orang tua dengan control kurang terhadap perilaku seksual berisiko sebanyak 34,4\% dan pengaruh teman sebaya dengan pengaruh jelek terhadap perilaku seksual berisiko sebanyak $29,3 \%$.

Variabel yang tidak berhubungan dengan perilaku seksual remaja yang tinggal dlingkungan Lokalisasi Kabupaten Sidoarjo adalah usia remaja akhir dengan perilaku seksual berisiko sebanyak 15,2\%, jenis kelamin perempuan dengan perilaku seksual berisiko sebanyak 14,3\%, tingkat pendidikan ibu yang dasar dengan perilaku seksual yang berisiko sebanyak 16,3\% dan tingkat pendidikan ayah yang menengah dengan perilaku seksual berisiko sebanyak $12,0 \%$, pekerjaan orang tua yang tidak bekerja dengan perilaku seksual berisiko sebanyak $16,7 \%$, pengetahuan kesehatan reproduksi IMS dan HIV/AIDS yang kurang dengan perilaku seksual berisiko sebanyak 22,2\% dan sikap terhadap 
seksualitas yang permisif dengan perilaku seksual berisiko sebanyak $20,0 \%$.

Variabel yang paling dominan berpengaruh terhadap perilaku seksual remaja yang tinggal dilingkungan lokalissasi Kabupaten Sidoarjo yaitu harga diri dengan nilai OR sebesar 17,480 $(95 \%$ CL : 2,445-124,962). Hal ini berarti bahwa responden dengan harga diri rendah memiliki kecenderungan lebih besar untuk melakukan perilaku seksual berisiko IMS dibandingkan dengan responden yang memiliki harga diri tinggi. Pengaruh orang tua dengan nilai OR sebesar 921,191 (95\% CL: 2,638-170,235). Hal ini berarti bahwa responden yang dapat pengaruh orang tua dengan control kurang memiliki kecenderungan lebih besar untuk melakukan perilaku seksual berisiko IMS dibandingkan dengan responden yang memiliki pengaruh orang tua dengan control baik.

Besar sumbangan variabel harga diri dan pengaruh orang tua terhadap perilaku seksual adalah sebesar 99\% yang artinya harga diri dan pengaruh orang tua yang baik akan dapat menyebabkan terjadinya perilaku seksual tidak berisiko sebanyak $99 \%$ dan sisanya $1 \%$ bisa dipengaruhi faktor lain.

\section{KEPUSTAKAAN}

Shaluhiyah, Zahro. Sexual Lifestyles and Inter-personal Relationships of
University Students in Central Java and Their Implication for Sexual and

Reproductive

Health.(Disertasi).2006

Depkes RI. Pedoman Nasional Perawatan, Dukungan dan Pengobatan Bagi ODHA Dirjen PPM\&PLP,Jakarta.2003. Jawa Pos. Remaja Harus Berani Beda (serial online).http://www.aidsindonesia.o $\underline{\text { r.id/index.php?option=com_content }}$ $\&$ task=view \&id=1235\&itemid=2.

Diakses pada tanggal 19 agustus 2008.

Elisabet Setya Asih Widyastuti. Faktor Personal dan Sosial yang mempengaruhi sikap remaja terhadap hubungan seksual pranikah. Studi di lokalisasi sunan kuning dan gambilang semarang. 2009.

Sarwono, S.W. Psiokologi remaja. Jakarta: PT Rsjs Grafindo Persada. 2003.

Susanto, Astri S. Pengantar Sosiologi dan Perubahan Sosial. Bandung Bina Cipta. 1979.

Resource Center For Adolescent Pregnancy Prevention. SociaL Learning Theory and Sexuality Education (Serial Online). http://www.etr.org/recapp/theorisie s/slt/SLTandsexEd.htm

U.S. Departemen Of Health and Human Service National Institutes Of 
Health Theory at a Glance: A Guide

For Health Promotion Practice.

(Serial

Online).

www.cancer.gov/theory. 1997.

Notoatmodjo, Soekidjo. Promosi

Kesehatan : Teori dan Aplikasi.

Rineka Cipta: Jakarta. 2005.

Huwiler SM, Remafedi G. Adolescent

Homosexuality.

AdvPediatr.

1998;45; 107-144

Notoatmodjo, Soekidjo. Ilmu Kesehatan

Masyarakat prinsip-prinsip dasar.

Rinekacipta : Jakarta.2003.

PKBI. Remaja, Kesehatan Reproduksi, Resiko Reproduksi dan Perkembangan Seksualitas. Jakarta; 2000 .

Anonymous. Peer Pressure vs Peer Motivation. 2004 [updated 2004; cited 201210 Februari]; Available from: www.e-psikologi.com.

PKBI, IPPF, BKKBN, UNFPA. Perkembangan Seksualitas Remaja Modul 2. Bandung: PKBI, UNFPA; 1999.

Rakmat, Jalaluddi. Psikologi Komunikasi Remaja Rosdakarya.

Bandung.2007.

Athinson etal citRiyanto P. Efektifitas Metode Ceramah dan Diskusi Kelompok Dalam Meningkatkan Pengetahuan dan Sikap Remaja Tentang Kesehatan Reproduksi. Thesis S2 Gadjahmada Yogyakarta.
Anonymous. Social Learning Theory and Sexuality Education (Serial Online) [cited

2012,11Maret];Availablefrom:

http://recapp.etr.org/recapp/index.c $\underline{\mathrm{fm} \text { ?fuseaction=pages. TheoriesDeta }}$ il\&PageID=380.

Notoatmodjo, S. Metedologi Penelitian Kesehatan. Jakarta: Rinekacipta. 2002

Lemeshow, Stanley. Besar Sampel Dalam Penelitian Kesehatan, Gajah Mada University Press, Yogyakarta. 2004. Ditjen PPM \& PL Depkes RI. Statistic kasus HIV/AIDS di Indonesia : dilaporkan s/d Desember 2008.

KPA Jawa Tengah. Kondisi HIV/AIDS. Jawa Tengah sampai dengan 2008.Diakses tanggal 24 april 2009,www.aidsjateng.or.id

Indonesia Warehouse Bagi Pelacuran Asean? Diakses pada tanggal 5 Maret 2011.http.//www.topix.com/forum/ world/Malaysia/TDRP02CUT80CT $\mathrm{M} 3 \mathrm{RF} / \mathrm{p} 3$

Pilar PKBI Jawa Timur. 2009. Data survey perilaku seks pada remaja terhadap mahasiswa Universitas Surabaya. 